\title{
ROLA MODLITWY W ŻYCIU SYRYJSKICH MNICHÓW WEDLUG TEODORETA Z CYRU
}

Modlitwa jest podstawową formą kultu ${ }^{1}$. Akty modlitewne są powszechne we wszystkich religiach, nie tylko w chrześcijaństwie. W wielu wyznaniach ukształtowały się reguły, których treść jest dokładnie określona i przekazywana wyznawcom. Modlitwa stanowiła jeden z najważniejszych celów życia chrześcijańskich mnichów. Syryjscy mnisi modlili się o różnych porach i w różnych postawach, znali także wiele rodzajów modlitw oraz zwracali się do Boga w różnych intencjach ${ }^{2}$. Teodoret, biskup $\mathrm{Cyru}^{3}$, poświęcił życiu syryjskich mnichów odrębne dzieło - Historia religiosa ${ }^{4}$. Zawarł w nim bardzo wiele szczegółów dotyczących ich modlitwy. Wśród trzydziestu rozdziałów tylko w dwóch (żywoty Jana ${ }^{5}$ i Asklepiosa ${ }^{6}$ ) nie znajdziemy żadnej wzmianki na ten temat. Rozdziały te należą do najkrótszych w dziele Teodoreta i być może tym należy thumaczyć brak wzmianki o modlitwie opisywanych w nich ascetów. Skoro Teodoret poświęcił wspomnianemu aspektowi aktywności

\footnotetext{
* Mgr Katarzyna Skotnicka - doktorantka przy Katedrze Historii Bizancjum w Instytucie Historii na Wydziale Filozoficzno-Historycznym Uniwersytetu Łódzkiego; e-mail: katarzynaskotnicka21@vp.pl.

${ }^{1}$ Por. J. Maciuszko, Modlitwa, w: Religia. Encyklopedia, red. nauk. T. Gadacz - B. Milerski, VII, Warszawa 2003, 109.

${ }^{2}$ Por. Aphraates, Demonstrationes (De oratione) 4, 1-19, ed. R. Graffin, PSyr 1, Paris 1894, 137-182, thum. A. Uciecha: Afrahat, O modlitwie, SSHT 43 (2010) 31-44.

${ }^{3}$ Literatura przedmiotu dotycząca Teodoreta z Cyru jest przebogata, por. E. Honigmann, Theodoret of Cyrrus and Basil of Seleucia. The Time of their Death, ST 173 (1953) 174-184; P. Canivet, Le monachisme syrien selon Theodoret de Cyr, Paris 1976, 37-63; M. Karas, Teodoret z Cyru, stawny czy zapomniany?, „Filomata” 1995, nr 425-426, 97-104; T. Urbainczyk, Theodoret of Cyrrhus. The Bishop and Holy Man, Michigan 2002; I.P. Kupan, Theodoret of Cyrus, LondonNew York 2006, 3-80; S. Bralewski, Teodoret z Cyru wobec dążé biskupów Rzymu do Prymatu, w: Byzantina Europaea. Ksiega Jubileuszowa ofiarowana profesorowi Waldemarowi Ceranowi, red. M. Kokokszko - M.J. Leszka, Byzantina Lodziensia XI, Łódź 2007, 69-80; D. Fairbairn, The puzzle of Theodorets Christology: a Modest suggestion, JTS 58 (2007) 100-133; J. Clayton - B. Paul, The Christology of Theodoret of Cyrus, Oxford 2007; V. Vranic, The Christology of Theodoret of Cyrrhus: The Question of Its Development, Milwaukee (Wisconsin) 2012.

${ }^{4} \mathrm{Na}$ temat samego dzieła, jego autentyczności i datowania por. Canivet, Le monachisme syrien, s. 27-35.

${ }^{5}$ Por. Theodoretus, Historia religiosa XXIII 1-2, PG 82, 1456C - 1457A, thum. K. Augustyniak: Teodoret z Cyru, Dzieje miłości Bożej. Historia mnichów syryjskich, ŹM 7, Kraków 1994, 250-251.

${ }^{6}$ Por. tamże XXV 1-2, PG 1464B-D, ŹM 7, 260-261.
} 
anachoretów tyle miejsca, to praktyka modlitwy musiała być dla niego bardzo ważna. $\mathrm{Z}$ tego względu w niniejszym artykule podjęto próbę przedstawienia, w jaki sposób postrzegał on w Dziejach miłości Bożej modlitwę i jej rolę w życiu syryjskich mnichów.

1. Istota modlitwy. Trzeba najpierw wyjaśnić, w jaki sposób biskup Cyru pojmował modlitwę. Wedle współczesnej definicji słownikowej modlitwą nazywamy akt religijny rozumiany jako myślowy lub słowny kontakt z Bogiem, zwykle w nastroju uwielbienia, dziękczynienia lub prośby. Modlitwa jest więc słowem (lub ustalonym tekstem) wypowiadanym przez modlącego się?

Sławny mnich Marcjan wywodzący się z Cyru, jak podkreślał Teodoret:

„rozmawiał jedynie z Panem wszechrzeczy i słuchał Jego słodkiego głosu.

Kiedy bowiem czytał boskie słowa, sądził, że cieszy się głosem Boga, a kiedy

się modlił i zanosił do Niego prośby, sam nawiązywał rozmowę z Panem"».

Tak więc dla biskupa Cyru modlitwa była przede wszystkim rozmową z Bogiem. Podobnie pojmował ją Ewagriusz z Pontu ${ }^{9}$, widząc w niej „obcowanie (ó $\mu \imath \lambda \hat{\imath} \alpha)$ umysłu z Bogiem"10. Termin ó $\mu \imath \lambda \hat{\imath} \alpha$ ma jednak wiele znaczeń ${ }^{11}$. W tym wypadku oznaczać może zarówno poufne obcowanie, jak i nieskrępowane, bezpośrednie mówienie ${ }^{12}$. Słowa ó $\mu \imath \lambda i_{\alpha} \alpha$ odniesieniu do modlitwy używał również Teodoret. W jego relacji dla anachorety Juliana z Osroene

${ }^{7}$ Por. Słownik Języka Polskiego, red. M. Szymczak, II, Warszawa 1995, 191.

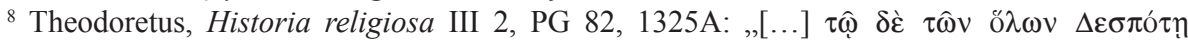

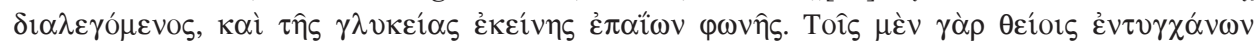

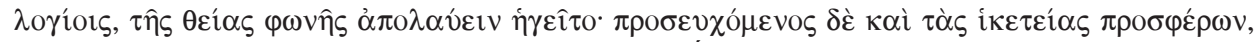

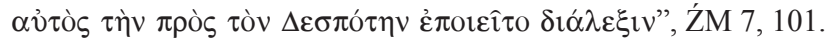

${ }^{9} \mathrm{Na}$ temat Ewagriusza i jego przemyśleń dotyczących modlitwy por. G. Bunge, The ,, Spiritual Prayer”: On the Trinitarian Mysticism of Evagrius of Pontus, „Monastic Studies” 17 (1987) 191208; J. Driscoll, Evagrius, Paphnutius, and the Reasons for Abandonment by God, SMon 40 (1998) 259-286; L. Dysinger, The Logoi of Providence and Judgment in the Exegetical Writings of Evagrius Ponticus, StPatr 37 (2001) 462-471; tenże, The Significance of Psalmody in the Mystical Theology of Evagrius of Pontus, StPatr 30 (1997) 176-182; W. Harmless, Salt for the Impure, Light for the Pure: Reflections on the Pedagogy of Evagrius Ponticus, StPatr 37 (2001) 514-526; B. McGinn, The Foundations of Mysticism: Origins to the Fifth Century. New York 1991; M. O'Laughlin, The Bible, the Demons, and the Desert: Evaluating the Antirrheticus of Evagrius Ponticus, SMon 34 (1992) 201-215; C. Stewart, Evagrius on Prayer and Anger, w: Religions of Late Antiquity in Practice, ed. R. Valantasis, Princeton 2000, 65-81; tenże, Imageless Prayer and the Theological Vision of Evagrius Ponticus, JECS 9 (2001) 173-204; R.D. Young, Evagrius the Iconographer: Monastic Pedagogy in the Gnostikos, JECS 9 (2001) 53-72.

${ }^{10}$ Evagrius, De oratione 3, PG 79, $1168 \mathrm{C}$, thum. K. Bielawski: Ewagriusz z Pontu, O modlitwie, w: Ewagriusz z Pontu, Pisma monastyczne, ŹM 18, Kraków 1998, 252.

11 'O $\mu \imath \lambda i ́ \alpha$ oznacza m.in. przebywanie razem, obcowanie z kimś, rozmowę, naukę, wykład, towarzystwo, zgromadzenie, grono; por. Abramowiczówna III 276.

${ }^{12}$ Por. G. Bunge, Ewagriusz z Pontu - mistrz życia duchowego. Modlitwa ducha, acedia, ojcostwo duchowe, tłum. J. Bednarek - A. Jastrzębski - A. Ziernicki, ŹM 19, Kraków 1998, 35. 
rozkoszą, upojeniem i ucztą wyśmienitą był śpiew psalmów Dawida i „stałe obcowanie (ó $\left.\mu \imath \lambda i^{\alpha} \alpha\right)$ z Bogiem"13. Obok wspomnianego terminu biskup Cyru stosował także zbliżone znaczeniowo wyrażenie $\pi \rho 0 \sigma o \mu \imath \lambda \varepsilon \hat{\imath} v^{14}$, które w tym kontekście trzeba rozumieć również jako obcowanie z Bogiem. Modlitwę nazywał też Teodoret służbą Bogu $\left(\lambda \varepsilon \imath \tau o v \rho \gamma^{\prime} \alpha\right)^{15}$. Określenia te zgadzają się także z współczesną definicją modlitwy, rozumianej jako uzewnętrznienie kontaktu człowieka ze Stwórcą za pomocą słów. Asceci syryjscy, według Teodoreta, modlili się nieustannie, aby być w ten sposób w łączności z Bogiem. Zebinas, mnich uprawiający ascezę na równinie Azas, miał modlić się dzień i noc, aby nawet przez chwilę nie być oddzielonym od Boga. Teodoret podkreślał też, że anachoreta ów przewyższał sobie współczesnych jeśli chodzi o gorliwość w modlitwie ${ }^{16}$.

Mianem modlitwy biskup Cyru określał również wszelkie prośby i błagania oraz dziękczynienia i uwielbienia ${ }^{17}$. Również współcześnie dokonuje się rozróżnienia modlitw na podstawie intencji, z jakimi ludzie zwracają się do Boga. Istnieją więc modlitwy dziękczynne, prośby, adoracje, przebłagania, uwielbienia i hołdy. Podział modlitw ze względu na intencję znany był nie tylko Teodoretowi. Przykładowo Jan Kasjan ${ }^{18}$ wyróżniał modlitwy błagalne, ofiarujące (w dziele biskupa Cyru nie ma fragmentów odnoszących się do tego rodzaju modlitwy), wstawiennicze i dziękczynne ${ }^{19}$. Orygenes natomiast nakazywał chwalić Boga, dziękować, wyznawać grzechy i prosić20. Jan Kasjan modlitwę błagalną definiuje następująco: „błaganie lub prośba za grzechy, czyli modlitwa ze skruchą o odpuszczenie dawnych lub obec-

${ }^{13}$ Theodoretus, Historia religiosa II 2, PG 82, 1308A, ŹM 7, 82. Na temat Juliana zwanego Sabą por. Canivet, Le monachisme syrien, s. 103-108.

${ }^{14}$ Theodoretus, Historia religiosa IV 5, PG 82, 1344B, ŹM 7, 122. Termin $\pi \rho \circ \sigma o \mu \imath \lambda \varepsilon ́ \omega$ oznacza: obcować z kimś, rozmawiać, załatwiać prywatne sprawy, rozprawiać, wykładać, być obeznanym, biegłym w czymś; por. Abramowiczówna III 717.

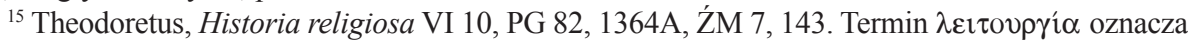
m.in. publiczną służbę, funkcję, usługę, publiczną służbę bożą, kult; por. Abramowiczówna III 20.

${ }_{16}^{16}$ Por. Theodoretus, Historia religiosa XXIV 1, PG 82, 1457B, ŹM 7, 252.

${ }^{17}$ Por. tamże II 14, PG 82, 1316D, ŹM 7, 92; IV 5, PG 82, 1344B, ŹM 7, 122.

${ }^{18} \mathrm{Na}$ temat Jana Kasjana por. C. Stewart, Kasjan Mnich, tłum. T. Lubowiecka, ŹM 34, Kraków 2004; K.S. Frank, John Cassian on John Cassian, StPatr 30 (1997) 418-433; J.J. Levko, Cassian's Prayer for the Twenty-First Century, Scranton 2000; C. Leyser, Authority and Asceticism from Augustine to Gregory the Great, New York 2001; C. Stewart, John Cassian on Unceasing Prayer, „Monastic Studies” 15 (1984) 159-177; C. Stewart, The Monastic Journey Accordingto John Cassian, „Word and Spirit” 19 (1993) 29-40.

${ }^{19}$ Por. Joannes Cassianus, Collationes Patrum IX 9-17, PL 49, 780C - 788B, thum. A. Nocoń: Jan Kasjan, Rozmowy z Ojcami, t. 1, ŹM 28, Kraków 2003, 385-392.

${ }^{20}$ Podstawowym źródłem, na którym opierano się, dokonując tego podziału, był fragment Pierwszego Listu św. Pawła do Tymoteusza (1Tm 2, 1): „Polecam więc - pisał Apostoł - przede wszystkim zanosić błagania, modlić się, prosić i dzięki czynić”. Por. M. Szram, Koncepcja modlitwy integralnej wedtug Orygenesa, VV 22 (2012) 185. 
nych win”21. Teodoret z Cyru natomiast twierdził, że polega ona na „modlitewnym wezwaniu o oddalenie jakichś przykrości”"22. W tym miejscu odwołać się można do przykładu uczniów Euzebiusza. Każdy z nich miał „błagać Pana i prosić o zbawienie”23. Była to więc typowa modlitwa błagalna. Warunkiem skuteczności takiej modlitwy było zachowanie czystości modlącego się człowieka ${ }^{24}$.

2. Modlitwa wstawiennicza. Wielokrotnie Teodoret opisywał modlitwy wstawiennicze. Wyróżnić można kilka kategorii spraw, które pustelnicy syryjscy starali się rozstrzygnąć przy pomocy modlitwy. Bardzo często prosili oni o płodność dla kobiet. Najlepszym przykładem może tu być historia narodzin samego Teodoreta, którego matka po wielu latach stała się brzemienną na skutek modlitwy ascety Macedoniusza ${ }^{25}$. Inny mnich, Roman, ,dla wielu niepłodnych niewiast uprosił dar urodzenia dzieci”26. Do podobnych celów modlitwę wykorzystywał Symeon Słupnik ${ }^{27}$, któremu - według Teodoreta - udało się wyprosić dar posiadania dziecka dla królowej Izmaelitów ${ }^{28}$. Zdarzało się, że o potomstwo prosili mężczyźni. Do Symeona Słupnika przybywali ludzie, którzy „wzywali pomocy, aby mogli zostać ojcami i za jego wstawiennictwem otrzymać to, czego nie dała im natura" 29 .

Zdecydowanie więcej przykładów z Historia religiosa, dotyczących modlitwy wstawienniczej, odnosi się do uzdrawiania. Ponownie można się tu odwołać do przykładu matki Teodoreta, która miała zostać uzdrowiona przez ascetę Piotra Galatę ${ }^{30}$. Za pomocą modlitwy Macedoniusz uleczył pewną bogatą kobietę z obżarstwa ( $\dot{\alpha} \delta \eta \dot{\varphi} \varphi \alpha \gamma o \varsigma)^{31}$. Innym razem asceta ten przybył do domu zamożnego człowieka o imieniu Awodian, którego żona, Astrion, cierpiała na chorobę mózgu ${ }^{32}$. Zgodnie ze słowami Teodoreta:

„natchniony mąż uległ prośbie, udał się do domu Awodiana i skierował do Boga gorącą modlitwę. Gdy skończył się modlić, polecił przynieść wodę,

${ }^{21}$ Joannes Cassianus, Collationes Patrum IX 11, PL 49, 783A, ŹM 28, 386.

${ }^{22}$ Theodoretus, Interpretatio In xiv epistulas Santi Pauli, PG 82, 797A, thum. S. Kalinkowski: Teodoret z Cyru, Komentarz do listów Pawłowych do Tesaloniczan, Tymoteusza, Tytusa, Filemona i Hebrajczyków, ŹMT 20, Kraków 2001, 140.

${ }^{23}$ Tenże, Historia religiosa IV 5, PG 82, 1344B, ŹM 7, 122.

${ }^{24}$ Por. L. Małunowiczówna, Antologia modlitwy wczesnochrześcijańskiej, Lublin 1993, 9.

${ }^{25}$ Por. Theodoretus, Historia religiosa XIII 16, PG 82, 1408D - 1409B, ŹM 7, 193-194.

${ }^{26}$ Tamże XI 4, PG 82, 1396A, ŹM 7, 178.

${ }^{27} \mathrm{Na}$ temat Symeona Shupnika por. S.A. Harvey, The Sense of a Stylite: Perspectives on Simeon the Elder, VigCh 42 (1988) 376-394; tenże, The Stylite's Liturgy: Ritual and Religious Identity in Late Antiquity, JECS 6 (1998) 523-539.

${ }^{28}$ Por. Theodoretus, Historia religiosa XXVI 21, PG 82, 1480C , ŹM 7, 278-279.

${ }^{29}$ Tamże XXVI 11, PG 82, 1472D, ŹM 7, 270.

${ }^{30}$ Por. tamże IX 7, PG 82, 1384A, ŹM 7, 163-164.

${ }^{31}$ Por. tamże XIII 9, PG 82, 1405A, ŹM 7, 189-190.

${ }^{32}$ Dosłowne thumaczenie to ,postradała zmysły”. 
uczynił nad nią znak zbawienia i kazał chorej pić. [...] Skoro tylko wypiła, przyszła do siebie i odzyskała rozum" "33.

W przypadku Maisymasa uzdrowienia doznać miało dziecko, przyniesione do ascety przez matkę. Zgodnie z opisem Teodoreta mnich:

„wziął dziecię na ręce, położył je u stóp ołtarza i upadł na twarz, błagając Lekarza dusz i ciał. Bóg wysłuchał jego prośby i oddał matce zdrowe dziecko"34.

Czasami asceta prosił także o to, by sam mógł odzyskać zdrowie. Tak postąpił Julian, który, ,jak to miał w zwyczaju, ukląkł, pochylił głowę ku ziemi i błagał o zdrowie" 35 .

Dzięki modlitwie wstawienniczej syryjscy asceci mieli także, według Teodoreta, dokonywać wskrzeszeń ${ }^{36}$. Biskup Cyru opisał trzy takie zdarzenia. Przykładowo Jakub z Nisibis „okazał swą cudowną moc, zwracając przez modlitwę życie leżącemu, którego przez modlitwę życia pozbawił"37. Podobnie postępował jego imiennik z okręgu Cyru, który - zgodnie ze słowami Teodoreta - „swoją modlitwą wskrzesił martwe dziecko"38. Trzecim ascetą, który według biskupa Cyru miał dokonać takiego cudu, był Palladiusz ${ }^{39}$. W Historia religiosa znajduje się także jeden przykład uzdrowienia zwierzęcia - Afraates miał uleczyć cesarskiego konia ${ }^{40}$.

Dzięki swojej modlitwie wstawienniczej asceci uzyskiwać mieli także władzę nad siłami przyrody. Przykładem może tu być Symeon Starszy, który według Teodoreta - potrafił zapanować nad pożarem: „ogień zgasł bez wody dzięki modlitwie i za wstawiennictwem świętego starca" "41. Dość ciekawy opis modlitwy wstawienniczej dotyczy oblężenia Nisibis ${ }^{42}$. Asceta Jakub, biskup

${ }^{33}$ Tamże XIII 13, PG 82, 1408B, ŹM 7, 192.

${ }^{34}$ Tamże XIV 3, PG 82, 1413A, ŹM 7, 199.

${ }^{35}$ Tamże II 18, PG 82, 1321B, ŹM 7, 97.

${ }^{36}$ Trudno jednoznacznie stwierdzić czy wydarzenia te rzeczywiście miały miejsce. Jednakże opisując te historie biskup Cyru powołuje się czasami na bezpośrednich świadków. Opowiadanie o uzdrowieniu swojej matki Teodoret z pewnością poznał bezpośrednio od niej samej. W przypadku uleczenia dziecka przez Maisymasa biskup Cyru pisze: „o tym dowiedziałem się właśnie od tej, która widziała cud i dostąpiła łaski uzdrowienia swego syna" (tamże XIV 3 PG 82, 1413A, ŹM 7, 199).

${ }^{37}$ Tamże I 8, PG 82, 1300A, ŹM 7, 73. We wspomnianej opowieści do Jakuba przychodzi grupa ludzi prosząc o pieniądze na pochówek swojego towarzysza. Człowiek ten w rzeczywistości żył, a całe przedstawienie miało na celu wyłudzenie pieniędzy od ascety. Jakub zaniósł do Pana modlitwę za duszę zmarłego, czym spowodował jego faktyczną śmierć. Kiedy ludzie zorientowali się, co się stało, przyznali się do próby oszustwa i prosili Jakuba o przywrócenie życia ich znajomemu. Na temat Jakuba z Nisibis por. Canivet, Le monachisme syrien, s. 104-108.

${ }^{38}$ Theodoretus, Historia religiosa XXI 14, PG 82, 1440B, ŹM 7, 231.

${ }^{39}$ Por. tamże VII 3, PG 82, 1365C, ŹM 7, 146.

${ }^{40}$ Por. tamże VIII 11, PG 82, 1376A-B, ŹM 7, 155-156.

${ }^{41}$ Tamże VI 5, PG 82, 1360D, ŹM 7, 140.

${ }^{42}$ Chodzi tu o oblężenie z roku 350, w trakcie najazdu króla Szapura na Mezopotamię rzymską. 
miasta, miał wejść na mury i „gdy ujrzał przed sobą ogromne rzesze nieprzyjaciół, prosił Boga, by zesłał na nich chmurę owadów i komarów. Jakub poprosił, a Bóg słuchając go jak Mojżesza, zesłał tę plagę"43.

W Historia religiosa jest tylko jeden taki przykład modlitwy dziękczynnej. Dotyczy on mnicha Juliana, który po śmierci cesarza Juliana Apostaty ${ }^{44}$ „słał pieśń dziękczynną Temu, który wybawia swoich"45. Brak takich informacji w przypadku pozostałych ascetów nie oznacza, że nie stosowali oni tego rodzaju modlitwy. Teodoret bardzo często wspomina bowiem, że mnisi zwracali się do Boga, nie tłumacząc jednocześnie, w jakiej intencji to robili.

3. Pora modlitwy. Bardzo ważną kwestią poruszaną przez Teodoreta był czas odmawiania modlitwy. Ideałem była tu tzw. modlitwa nieustanna. Aby jak najwięcej miejsca poświęcić na rozmowę z Bogiem, mnisi ograniczali czas przeznaczony na sen, jedzenie czy kontakty z ludźmi. Mnichem starającym się wypełniać ten nakaz był Zebinas, który „na modlitwie spędzał dzień i noc, i nie tylko nigdy nie miał jej dosyć, lecz coraz gorętsze odczuwał jej pragnienie" ${ }^{46}$. Również Teodozjusz żył „oddając się nieustannie modlitwie i śpiewaniu psalmów”47. Symeon Starszy natomiast „,nieustannie rozmawiał z Bogiem Wszechrzeczy" "48. Inny asceta, Euzebiusz, zachęcał swoich uczniów, „aby stale rozmawiali z Bogiem i nie dawali żadnej chwili upłynąć bez tej rozmowy"49. Przykładów modlitwy nieustannej jest więc w Historia religiosa dużo. Postępowanie takie niosło ze sobą pewne oczywiste trudności. Ojcowie Kościoła zalecają w swoich pismach długie modlitwy, nawet jeśli mają one być odmawiane kosztem pozbawienia się wypoczynku ${ }^{50}$. Jednak każdy, nawet najbardziej zaprawiony w ascetycznych umartwieniach mnich, musiał przerywać swoją modlitwę na sen, posiłek lub pracę. W Historia religiosa znajduje się także kilka opisów odwiedzin gości jako przykładów przeszkody na drodze do osiągnięcia modlitwy nieustannej. Przykładowo Zebinas:

„Z tymi, którzy go odwiedzali, rozmawiał krótko, gdyż nie chciał odwracać swojej myśli od nieba; gdy tylko się uwolnił od gości, natychmiast wracał do modlitwy" ${ }^{\prime 1}$.

\footnotetext{
Jakub był biskupem Nisibis. Nie jest jednak możliwe, by brał udział w obronie miasta, gdyż w tym roku już nie żył.

${ }^{43}$ Tamże I 11, PG 82, 1304D, ŹM 7, 79.

${ }^{44}$ Cesarz zginął 26 czerwca 363 r. w trakcie wyprawy przeciwko Persom.

${ }^{45}$ Tamże II 14, PG 82, 1316D, ŹM 7, 92.

${ }^{46}$ Tamże XXIV 1, PG 82, 1457B, ŹM 7, 252.

${ }^{47}$ Tamże X 2, PG 82, 1389A, ŹM 7, 171.

${ }^{48}$ Tamże VI 1, PG 82, 1357C, ŹM 7, 137.

${ }^{49}$ Tamże IV 5, PG 82, 1344B, ŹM 7, 122.

${ }^{50}$ Por. J. Górny, Modlitwa w życiu wspólnot monastycznych w świetle pism św. Hieronima, TST 8 (1981) 241.

${ }^{51}$ Theodoretus, Historia religiosa XXIV 1, PG 82, 1457B, ŹM 7, 252.
} 
Asceta Jakub oskarżany był o „zgryźliwe usposobienie”,52, ponieważ gniewał się na ludzi, którzy przeszkadzają mu w czasie modlitwy i najczęściej odprawiał ich bez błogosławieństwa. Również Symeon Słupnik, który „,w ciągu całej nocy i w dzień do godziny dziewiątej modli się bez przerwy" "53, musiał zrobić przerwę, aby od tej godziny aż do zachodu słońca zajmować się uzdrowieniami, wysłuchiwaniem próśb i rozstrzyganiem sporów. Żaden człowiek nie byłby więc w stanie wypełnić nakazu modlitwy nieustannej, jeśli rozumiano by go dosłownie. Problem ten Ojcowie Kościoła starali się rozwiązać twierdząc, że modlitwą jest już sama pamięć o ciągłej obecności Bożej ${ }^{54}$.

W Historia religiosa jest tylko kilka wypowiedzi dotyczących czasu odmawiania modlitwy. Anachoreci mogli modlić się o każdej porze dnia i nocy. $\mathrm{Ci}$ asceci, którzy mieszkali w klasztorach, musieli podporządkować się zasadom, które narzucała im reguła. Przykładem może tu być zgromadzenie założone przez Publiusza, który:

„wzniósł świątynię Bożą, w której mieli się zbierać jedni i drudzy ${ }^{55}$ z początkiem i końcem dnia, aby hymnem porannym i wieczornym wspólnie oddać chwałę Bogu"s6.

Dość dokładne informacje na temat czasu modlitwy w syryjskich klasztorach Teodoret przekazywał w przypadku ascety Juliana i jego uczniów ${ }^{57}$. Wiemy, że rozpoczynali oni swoją modlitwę z nastaniem jutrzenki i kontynuowali ją bez przerwy aż do wieczora, kiedy to następowała krótka przerwa. Teodoret wspominał, że mnisi:

„przed zachodem słońca odpoczywali nieco, następnie ze wszystkich stron, jedni stąd, inni stamtąd, schodzili się do jaskini i razem zanosili do Pana wieczorny hymn"s8.

${ }^{52}$ Tamże XXI 32, PG 82, 1449C, ŹM 7, 242.

${ }^{53}$ Tamże XXVI 26, PG 82, 1484A, ŹM 7, 281. Trudno jest dokładnie określić, która to jest godzina według czasu stosowanego współcześnie. Długość godzin zależała bowiem od pory roku. Najczęściej w świecie starożytnym stosowano godziny egipskie. Egipcjanie dzielili dobę na 12 godzin dziennych i 12 godzin nocnych. Godziny dzienne liczono od wschodu do zachodu słońca. Tak więc świt wyznaczał początek pierwszej godziny, południe zaczynało się z szóstą godziną, a zachód kończył ostatnią, dwunastą. Oznaczało to, że godzina dziewiąta wypadała mniej więcej w połowie między południem a zachodem słońca; por. L. Zajdler, Dzieje zegara, Warszawa 1980, 85-87).

${ }^{54}$ Por. A. Bober, Modlitwa patrystyczna, TST 8 (1981) 91.

${ }^{55}$ Mowa o dwóch grupach mnichów - posługujących się językiem greckim i syryjskim. Publiusz zbudował dla obydwu tych grup klasztor, w którym mnisi mieszkali w oddzielnych budynkach, ale modlili się wspólnie; por. P. Szczur, Jan Chryzostom a duszpasterstwo osób nie mówiących po grecku, VoxP 30 (2010) t. 55, 613-614.

${ }^{56}$ Theodoretus, Historia religiosa V 5, PG 82, 1353D, ŹM 7, 133.

${ }^{57}$ Zamieszkiwali oni klasztor w Gallaba (Gellab).

${ }^{58}$ Tamże II 5, PG 82, 1309C, ŹM 7, 85. 
Podane fragmenty odnoszą się do dwóch bardzo popularnych rodzajów modlitw - porannej i wieczornej ${ }^{59}$. O modlitwie porannej Teodoret informował po raz kolejny, opisując pielgrzymkę Symeona Starszego i jego towarzyszy na Synaj. Asceci mieli w trakcie swojej podróży spotkać innego mnicha, który poczęstował ich daktylami, ,a rano po zakończeniu służby Bożej pożegnał ich"60. Rano i wieczorem modliła się także Domnina ${ }^{61}$. Zgodnie z relacją Teodoreta nie była to jednak modlitwa prywatna. Ascetka ta codziennie chodziła do kościoła. Teodoret opisywał jej postępowanie następująco:

„gdy zapieją koguty, udaje się do niedalekiej świątyni Bożej i razem z innymi kobietami i mężczyznami śpiewa Bogu Wszechświata pochwalne hymny. Czyni tak nie tylko na początku, ale i na końcu dnia" ${ }^{2}$.

Zazwyczaj do modlitwy tej przystępowano, kiedy na niebie pojawiła się pierwsza gwiazda ${ }^{63}$. Pierwsze formuly dla modlitw porannej i wieczornej pojawiły się już w II wieku ${ }^{64}$. Najstarszym hymnem wieczornym jest $\Phi \hat{\omega} \zeta$ i $\lambda \alpha \rho \mathrm{v}^{65}$.

Część syryjskich mnichów decydowała się także na nocne czuwania. Okres ten uważano za bardzo dobrą porę na modlitwę. Sądzono bowiem, że Bóg słucha wtedy modlących się ludzi ze szczególną uwagą ${ }^{66}$. Do modlitwy nocnej zachęcał także Jan Chryzostom, nazywając wspaniałą rzeczą śpiewanie psalmów o tej porze ${ }^{67}$. W Historia religiosa mamy kilka opisów nocnych modlitw. Przy-

\footnotetext{
${ }^{59}$ Modlitwa poranna i wieczorna znana była także m.in. wspólnocie z Qumran; por. Z.J. Kapera, Modlitwa w tekstach qumrańskich. Zwięzłe wprowadzenie w problematykę, RBL 64 (2011) 11.

${ }^{60}$ Theodoretus, Historia religiosa VI 10, PG 82, 1364A, ŹM 7, 143.

${ }^{61} \mathrm{O}$ kobiecym ascetyzmie, nie tylko w Syrii, ale w całym świecie chrześcijańskim por. S. Elm, Virgins of God: The Making of Asceticism in Late Antiquity, New York 1994; G. Clark, Women and Asceticism in Late Antiquity, w: Asceticism, ed. V.L. Wimbush - R. Valantasis, New York 1995, 3348; C. Stewart, The Desert Mothers: The Portrayal of Women in the Sayings and Stories of the Desert, „Vox Benedictina” 2 (1985) 5-23; B. Ward, Apophthegmata Matrum, StPatr 16 (1985) 63-66.

${ }^{62}$ Theodoretus, Historia religiosa XXX 1, PG 82, 1492D, ŹM 7, 295.

${ }^{63}$ Por. Bober, Modlitwa patrystyczna, s. 92.

${ }^{64}$ Por. tamże, s. 92.

${ }^{65}$ Por. AP 486.

${ }^{66}$ Por. A. Vööbus, History of asceticism in the Syrian Orient. A contribution to the history and culture in the near East, CSCO 184, Louvain 1958, 287.

${ }^{67}$ Por. Joannes Chrysostomus, In Epistolam ad Thimoteum hom. 14, 4, PG 62, 575-576, thum. T. Sinko: Jan Chryzostom, Homilie na Listy Pasterskie Św. Pawła i na List do Filemona (Tym. I, II. Tyt. Filem.), Kraków 1949, 149-151. O odwołaniach do modlitwy w twórczości Jana Chryzostoma por. P. Szczur, Modlitwa dziękczynienia w świetle „Homilii na 1 List do Tymoteusza” św. Jana Chryzostoma, w: Modlitwa dziękczynienia, red. J. Misiurek - J. Popławski - K. Burski, Homo orans 6, Lublin 2005, 73-81; tenże, Nauka Jana Chryzostoma o modlitwie w świetle Homilii na 1 list św. Pawła do Tymoteusza, TPatr 5 (2008) 117-132; tenże, Warunki wystuchania modlitwy indywidualnej na przykladzie modlitwy Dawida w ,Objaśnieniach Psalmów” św. Jana Chryzostoma, w: Modlitwa wspólnotowa i indywidualna, red. J. Popławski - J. Misiurek - J. Miczyński, Homo orans 10, Lublin 2011, 17-37.
} 
kładowo asceta Polichroniusz „czuwa całą noc w postawie stojącej” ${ }^{68}$. Wśród mnichów, którzy modlili się w nocy, wymienić można także Zebinasa ${ }^{69}$, Abba$\mathrm{sa}^{70}$, Palladiusza ${ }^{71}$, Jakuba $^{72}$ i Abrahamesa, który „W nocy śpiewał czterdzieści psalmów w formie antyfon, podwajając tę liczbę przez dodanie modlitw"73. Do kwestii rozróżnienia modlitwy od psalmu wrócę w dalszej części artykułu. Mnisi modlili się także przed i po posiłku ${ }^{74}$. Choć Teodoret nie podaje takich przykładów, to można je znaleźć u Jana Chryzostoma, który cytuje modlitwę mnichów syryjskich odmawianą przy takich okazjach ${ }^{75}$.

4. Miejsce modlitwy. Ważną kwestią dotyczącą modlitwy, oprócz czasu jej odmawiania, było także miejsce, gdzie można było się modlić ${ }^{76}$. Mnisi syryjscy, oddając się modlitwie, dążyli do samotności. Chęć jej osiągnięcia była jednym z powodów wybierania na swoje siedziby miejsc oddalonych od osiedli ludzkich. Odsunięcie się od świata ułatwiało mnichom koncentrację na modlitwie. Przykładowo uczniowie Juliana codziennie opuszczali jaskinię, w której mieszkali i szli na pustynię, by tam się modlić ${ }^{77}$. Inni mnisi pozostawali w swoich domkach, zamurowując drzwi lub odgradzając się od świata murem $^{78}$. Taką samotną modlitwę wielu syryjskich ascetów uważało za najskuteczniejszą i najbardziej zbliżającą ich do Boga. Samotność w trakcie modlitwy zalecał mnichom także Jan Kasjan ${ }^{79}$. Przyczyniała się ona do stworzenia odpowiedniego klimatu, który sprzyjał modlitwie. Aby modlić się dobrze, człowiek powinien odejść od otaczającego go świata oraz zaprzestać wszelkiej innej działalności ${ }^{80}$.

Jedyne wątpliwości co do wyboru miejsca modlitwy budziła wśród Ojców Kościoła pewna sprzeczność pomiędzy fragmentem Ewangelii św. Mateusza, opisującym Kazanie na górze, a Listem św. Pawła do Tymoteusza. Ewangelista bowiem wspomina słowa Jezusa, który mówił: „A ty, kiedy się modlisz, wejdź do swej komórki i, zamknąwszy drzwi, módl się w ukryciu do swego Ojca"

${ }^{68}$ Theodoretus, Historia religiosa XXIV 4, PG 82, 1460A, ŹM 7, 254.

${ }^{69}$ Por. tamże XXIV 1, PG 82, 1457B, ŹM 7, 252.

${ }^{70}$ Por. tamże IV 12, PG 82, 1352A, ŹM 7, 128.

${ }^{71}$ Por. tamże VII 1, PG 82, 1365A, ŹM 7, 145.

${ }^{72}$ Por. tamże XXI 13, PG 82, 1440A, ŹM 7, 231.

${ }^{73}$ Tamże XVII 6, PG 82, 1421D, ŹM 7, 211.

${ }^{74}$ Por. L. Małunowiczówna, Modlitwa prywatna starożytnych chrześcijan, TST 8 (1981) 211.

${ }^{75}$ Por. Joannes Chrysostomus, In Epistolam ad Thimoteum hom. 14. 4, PG 62, 575-576, thum. Sinko, s. 149-151.

${ }^{76} \mathrm{O}$ miejscu modlitwy chrześcijan w czasach apostolskich por. W. Burda, Modlitwa Kościoła w Dziejach Apostolskich, VV 22 (2012) 114-120.

${ }^{77}$ Por. Theodoretus, Historia religiosa II 5, PG 82, 1309C, ŹM 7, 85.

${ }^{78}$ Por. tamże XVIII 1, PG 82, 1425C, ŹM 7, 216; XXII 3, PG 82, 1453B, ŹM 7, 247; XXVI 10, PG 82, 1472B, ŹM 7, 269.

${ }^{79}$ Por. Joannes Cassianus, Collationes Patrum IX 35, PL 49, 816A - 817B, ŹM 28, 414-415.

${ }^{80}$ Por. T. Krupnik, Modlitwa w życiu mniszym wedtug Jana Kasjana, Kraków 1998, 31. 
(Mt 6, 6), św. Paweł natomiast twierdził, że modlić się należy na każdym miejscu (por. 1Tm 2, 8). Większość ascetów kierowała się tekstem listu św. Pawła. Dla nich każde miejsce było odpowiednie, aby prowadzić rozmowę z Bogiem. Zresztą część Ojców Kościoła również uważała podobnie. Tertulian podkreślał, że człowiek może modlić się na każdym miejscu ${ }^{81}$. Podobnie twierdził Orygenes, choć miał pewne wątpliwości co do modlitw w małżeńskiej sypialni ${ }^{82}$. Jeśli chodzi o mnichów syryjskich, to przykładowo uczniowie Euzebiusza mogli modlić się „,bądź to w cieniu drzewa, bądź na skale, bądź tam, gdzie mogli korzystać z ciszy" 83 . Wiemy również, że część z nich udawała się na modlitwę do pobliskich kościołów. Tak postępowała Domnina ${ }^{84}$ oraz Publiusz i jego uczniowie ${ }^{85}$. W obydwu tych przypadkach chodzi o uczęszczanie do kościoła na modlitwę poranną i wieczorną ${ }^{86}$. Teodoret nie wyklucza, że asceci ci odmawiali również modlitwy prywatnie, poza murami świątyni. Również w przypadku Euzebiusza dowiadujemy się, że chodził „do domu modlitwy” ${ }^{7}$. Nie można jednoznacznie stwierdzić, że w tym wypadku chodzi o kościół. Dom modlitwy mógł być równie dobrze zwykłym budynkiem, przeznaczonym do tego rodzaju praktyk religijnych. O potrzebie wyznaczenia miejsca na modlitwę wspomniał Orygenes. Jego rada skierowana była nie tylko do mnichów, ale do ogółu wiernych. Doradzał on, aby w każdym domu wyznaczyć miejsce, które zapewni modlącemu się spokój i możliwość skupienia ${ }^{88}$. Wiadomo dzięki badaniom archeologicznym, że w egipskich Celach każdy $\mathrm{z}$ eremów posiadał oddzielne oratorium ${ }^{89}$.

5. Postawy i gesty modlitewne. Ważną kwestią dotyczącą modlitwy była postawa, jaką należało przyjąć w trakcie jej odmawiania oraz gesty, które jej towarzyszyły. Było to niezwykle istotne ponieważ modląc się człowiek stawał przed Bożym majestatem ${ }^{90}$. O tym jak ważna jest pozycja ciała, przekonu-

${ }^{81}$ Por. Tertullianus, De oratione 24, PL 1, 1192A, thum. W. Kania, w: Małunowiczówna, Antologia modlitwy wczesnochrześcijańskiej, s. 56.

${ }^{82}$ Por. Origenes, De oratione 31, 4, PG 11, 552C - 553A, thum. K. Augustyniak, w: Małunowiczówna, Antologia modlitwy wczesnochrześcijańskiej, s. 47.

${ }^{83}$ Theodoretus, Historia religiosa IV 5, PG 82, 1344B, ŹM 7, 122.

${ }^{84}$ Por. tamże XXX 1, PG 82, 1492D, ŹM 7, 291.

${ }^{85}$ Por. tamże V 5, PG 82, 1353D, ŹM 7, 133.

${ }^{86}$ Domnina uczęszczała do kościoła nie tylko na początku, ale i na końcu dnia (tamże XXX 1, PG 82, 1492D, ŹM 7, 295); również uczniowie Publiusza zbierają się w zbudowanej przez niego świątyni z początkiem i końcem dnia (tamże V 5, PG 82, 1353D, ŹM 7, 133).

${ }^{87}$ Tamże IV 6, PG 82, 1344C, ŹM 7, 123.

${ }^{88}$ Por. Origenes, De oratione 31, 4, PG 11, 552C - 553A thum. K. Augustyniak, w: Małunowiczówna, Antologia modlitwy wczesnochrześcijańskiej, s. 47.

${ }^{89}$ Por. E. Makowiecka, Cele - wyniki badań archeologicznych, w: Apoftegmaty Ojców Pustyni, t. 1: Gerontikon, ŹM 4, Kraków 2004², 79.

${ }^{90}$ Por. Z. Krzyszowski, Modlitwa znakiem wiarygodności Kościoła w eklezjologii patrystycznej, VoxP 28 (2008) t. 52, 567. 
je Cyprian ${ }^{91}$ : „Pamiętajmy, że stoimy przed obliczem Boga. Oczom Bożym trzeba się zaś podobać i postawą ciała, i ułożeniem głosu"92. Pustelnik rozpoczynający swoją rozmowę z Bogiem miał do wyboru wiele pozycji i gestów. Ich różnorodność była konsekwencją istnienia wielu rodzajów modlitw. Konkretna postawa była wybierana w zależności od tego czy mnich chciał Boga przepraszać czy prosić o jakąś łaskę. Pustelnik, który zwracał się do Boga wołając o wybaczenie, najprawdopodobniej przyjąłby pozycję klęczą$\mathrm{cą}^{93}$. Nie oznacza to jednak, że każda postawa była z góry dopasowana do rodzaju modlitwy.

Większość gestów wykonywanych w trakcie modlitwy została zaczerpnięta $\mathrm{z}$ tradycji pogańskiej oraz żydowskiej ${ }^{94}$. Przykłady na taką zależność znaleźć można m.in. u Tertuliana, który krytykuje chrześcijan za przejęcie od pogan zwyczaju siadania po modlitwie ${ }^{95}$. Chrześcijanie nadali przejętym gestom nowe znaczenie. Można było modlić się w każdej pozycji: stojącej, klęczącej, siedzącej, a nawet leżącej. Spośród wszystkich wymienionych Historia religiosa nie podaje jedynie przykładu modlitwy na siedząco. Ważna była również kwestia rąk, które bardzo często, choć nie zawsze, trzymano wzniesione. Podobnie sprawa wyglądała w przypadku oczu - można było wpatrywać się w niebo lub spuścić wzrok.

W Historia religiosa znaleźć możemy przykłady bardzo wielu różnych pozycji, które przyjmowali modlący się mnisi. Bardzo często modlitwę odmawiano w postawie stojącej. Syryjscy asceci, którzy modlili się w ten sposób, to: Baradat ${ }^{96}$, Symeon Słupnik ${ }^{97}$, Zebinas ${ }^{98}$, Euzebiusz i jego uczniowie ${ }^{99}$ oraz Julian ze swoimi naśladowcami ${ }^{100}$. Taka pozycja miała swoją symbolikę - była wyrazem szacunku. Stojąc okazywano cześć wobec majestatu Stwórcy ${ }^{101}$. Dodatkowo był to także symbol ciągłej gotowości do służenia Bogu i oczekiwania na Jego przyjście. Może być ona traktowana jako analogia do postawy żołnierza przed dowódcą ${ }^{102}$. Oczywiście wielogodzinne stanie w pozycji wyprostowanej traktowane być mogło jako rodzaj umartwienia.

${ }^{91} \mathrm{O}$ modlitwie w twórczości Cypriana por. S. Wasilewski, Modlitwa Ojcze nasz jako chrześcijańskie wyznanie wiary na podstawie „De Dominica Oratione” Cypriana z Kartaginy, SLov 15 (2013) 319-349.

${ }^{92}$ Cyprianus, De dominica oratione 4, PL 4, 521B, thum. J. Czuj, w: Małunowiczówna, Antologia modlitwy wczesnochrześcijańskiej, s. 58.

${ }^{93}$ Por. P. Szpyrka, Gest w modlitwie pierwszych chrześcijan (II), PP 123 (2006) nr 2, 61.

${ }^{94}$ Por. tenże, Gest w modlitwie pierwszych chrześcijan (I), PP 123 (2006) nr 1, 46.

${ }^{95}$ Tertullianus, De oratione 16, PL 1, 1171A - 1174A, thum. Kania, s. 55.

${ }^{96}$ Por. Theodoretus, Historia religiosa XXVII 3, PG 82, 1485C, ŹM 7, 285.

${ }^{97}$ Por. tamże XXVI 22, PG 82, 1480D - 1481A, ŹM 7, 279.

${ }^{98}$ Por. tamże XXIV 1, PG 82, 1457B, ŹM 7, 252.

${ }^{99}$ Por. tamże IV 5, PG 82, 1344B, ŹM 7, 122.

${ }^{100}$ Por. tamże II 5, PG 82, 1309B-C, ŹM 7, 85.

${ }^{101}$ Por. Szpyrka, Gest w modlitwie (II), s. 46.

${ }^{102}$ Por. tamże, s. 48. 
Należy tu jednak zwrócić uwagę, że modlitwa w pozycji stojącej nie zawsze oznaczała to samo. Różnice dotyczyły przykładów ułożenia rąk czy kierunku, w którym spoglądano. Przykładowo Baradat „,bez przerwy stoi z rękami wyciągniętymi ku niebu, sławiąc Boga Wszechświata"103. Wznoszenie rąk było bardzo popularnym gestem modlitewnym. Choć wywodzi się z tradycji żydowskiej (por. przykładowo Wj 9, 29; 10, 22; 17, 11) ma także swoje nowotestamentowe uzasadnienie. Bardzo ważny dla chrześcijan był tu tekst Pierwszego listu św. Pawła do Tymoteusza $(2,8)$ : „Chcę więc, żeby mężczyźni modlili się na każdym miejscu, wznosząc czyste ręce, bez gniewu i kłótni”. Ojcowie Kościoła zdawali sobie sprawę, że gest ten wykorzystywany był także w modlitwach pogańskich i żydowskich, dlatego starali się nadać mu nową, chrześcijańską symbolikę. Znaczenie wyciągniętych ku górze rąk wyjaśnia m.in. Orygenes, który twierdzi, że człowiek, który przygotowuje się do modlitwy, „zanim podniesie ręce wzniesie, że tak powiem duszę"104. Podniesione ręce są więc symbolem chęci zbliżenia się do nieba, w którym miał przebywać Bóg. Wyciągnięcie rąk to także dowód na podporządkowanie się swojemu Stwórcy. Jednocześnie modlący się chrześcijanin miał nadzieję, że gestem tym zwróci uwagę Boga na swoją modlitwę ${ }^{105}$. Należy także zwrócić uwagę na analogię tej pozycji do postawy dziecka, zwracającego się o pomoc ${ }^{106}$. Gest wyciągniętych w górę rąk wyjaśniał także sam Teodoret, zaznaczając:

„podnoszenie rąk przy modlitwie było zastrzeżone dla kapłanów Starego Testamentu, jednakże święty Apostoł nakazał czynić tak wszystkim ludziom, ponieważ wszyscy stali się «ludem wybranym, królewskim kapłaństwem, narodem świętym» (por. 1P 2, 9)"'107.

Gest uniesionych rąk był znany w Egipcie. Stosował go m.in. abba Makary Egipcjanin ${ }^{108}$. Choć w Historia religiosa znajduje się przykład tylko jednego mnicha modlącego się $\mathrm{z}$ wyciągniętymi ramionami - jest to właśnie wspomniany wyżej Baradat - to $\mathrm{z}$ całą pewnością podobną postawę przyjmowali także inni pustelnicy. Pozycja ta była bowiem bardzo popularna wśród ówczesnych chrześcijan, a Teodoret mógł ją pominąć opisując pozostałych ascetów właśnie ze względu na jej oczywistość.

Ważnym gestem w trakcie modlitwy było też wznoszenie oczu ku niebu. Również ten gest ma pochodzenie biblijne ${ }^{109}$. Przykładem może tu być Księga Psalmów (por. Ps 25, 15; 123, 1), a w Nowym Testamencie postępowanie

${ }^{103}$ Theodoretus, Historia religiosa XXVII 3, PG 82, 1485C, ŹM 7, 285.

${ }^{104}$ Origenes, De oratione 31, 2, PG 11, 549C, thum. K. Augustyniak, w: Małunowiczówna, Antologia modlitwy wczesnochrześcijańskiej, s. 45.

${ }^{105}$ Por. Szpyrka, Gest w modlitwie (II), s. 52.

${ }^{106}$ Por. tamże, s. 52.

${ }^{107}$ Theodoretus, Interpretatio Epistulae I ad Timotheum 2, 8, PG 82, 800D - 801A, ŹMT 20, 143.

${ }^{108}$ Por. Apophtegmata Patrum 19 (472), PG 65, 269C, thum. M. Borkowska, w: Apoftegmaty Ojców Pustyni, t. 1: Gerontikon, ŹM 4, 336.

${ }^{109}$ Por. Szpyrka, Gest w modlitwie (II), s. 55. 
Jezusa, który modląc się, czy uzdrawiając wznosił oczy ku niebu (por. Mk 7, 31-35; Mt 14, 18-20; J 11, 38-44; 17, 1). Teodoret nie podał przykładu pustelnika modlącego się z oczami zwróconymi ku górze. Nie oznacza to jednak, że syryjscy asceci nie praktykowali tego rodzaju postawy. $Z$ pewnością była ona popularna w chrześcijańskim świecie, skoro w rozprawie $O$ modlitwie wspomina o niej Tertulian, doradzając, żeby nie podnosić wzroku zbyt wysoko, bo może to być przejaw pychy ${ }^{110}$. Podobne zdanie miał Ewagriusz ${ }^{111}$. Być może, podobnie jak w przypadku wzniesionych rąk, oczywistość tego gestu spowodowała jego nieuwzględnienie w opisie modlitw syryjskich mnichów, dokonanym przez Teodoreta.

Zdarza się także, że modlitwa w postawie stojącej przerywana była pokłonami. Przykładem jest tu Symeon Słupnik, który:

„raz stoi prosto przez dłuższy czas, to znowu często się pochyla i oddaje cześć Bogu. Wielu spośród obecnych liczy te pokłony. Raz jedna z towarzyszących mi osób naliczyła tysiąc dwieście czterdzieści cztery, po czym zmęczyła się i przestała liczyć. Pochylając się zawsze czołem dotyka palców stóp"112.

Wykonanie takich skłonów wymagałoby dużej sprawności fizycznej. Mowa tu jednak o pustelniku, który podobne ćwiczenia wykonywał całymi latami - mógł więc zdobyć w tym czasie podobną sprawność. Podobne postępowanie musiało być wyjątkowo ciężkie dla osoby, której ciało było dodatkowo osłabione surowymi postami (była to więc forma umartwienia połączonego z modlitwą). Relację Teodoreta uwiarygodnia jednak fakt, że sam był świadkiem takiego postępowania.

Często w trakcie modlitwy przyjmowano pozycję klęczącą. Była ona uważana za jedną $\mathrm{z}$ najpiękniejszych postaw przyjmowanych $\mathrm{w}$ trakcie rozmowy $z$ Bogiem ${ }^{113}$. Informacje na temat stosowania tej postawy przy modlitwie znajdziemy również w Historia religiosa. W przypadku mnicha Juliana mamy aż trzy fragmenty mówiące o przyjęciu takiej pozycji. Dowiadujemy się więc, że asceta ten:

„przyuczał ich [swoich uczniów] także, by w jaskini wspólnie śpiewali Bogu hymny; z nastaniem zaś jutrzenki wychodzili po dwóch na pustynię - jeden na kolanach miał oddawać należną cześć Panu, drugi zaś stojąc miał śpiewać piętnaście Dawidowych psalmów, potem zmieniał role i jeden stojąc, śpiewał, drugi, klęcząc na ziemi, oddawał cześć"114.

${ }^{110}$ Por. Tertullianus, De oratione 16-17, PL 1, 1171A - 1176A, tłum. Kania, s. 55.

${ }^{111}$ Por. Evagrius, De oratione 110, PG 79, 1186, ŹM 18, 270.

112 Theodoretus, Historia religiosa XXVI 22, PG 82, 1481A, ŹM 7, 279.

113 Por. W. Kania, Pierwsza naukowa rozprawa o modlitwie Orygenesa Peri Euches, TST 8 (1981) 135.

${ }^{114}$ Theodoretus, Historia religiosa II 5, PG 82, 1309B-C, ŹM 7, 85. 
W tym wypadku postawa klęcząca była stosowana wymiennie ze stojącą. Podobnie postępował Abbas, który „większą część dnia i nocy wypełniał wobec Pana służbę modlitewną na stojąco lub na kolanach"115. Stosowanie danej postawy zależne było od okoliczności, bardzo ważna była tu kwestia rodzaju modlitwy, którą w tym czasie odmawiał pustelnik. Zazwyczaj klękano gdy zwracano się do Boga z jakąs szczególnie ważną prośbą ${ }^{116}$. Tak postąpił wspomniany już Julian, który ,jak to miał w zwyczaju, ukląkł, pochylił głowę ku ziemi i błagał o zdrowie, jeśli jego odzyskanie miałoby przynieść jakąś korzyść zebranym" ${ }^{117}$. Innym razem ,ukląkł i zraszając ziemię gorącymi łzami błagał Pana o wybawienie z trudności" ${ }^{118}$. Również w tym wypadku zwracał się do Boga z bardzo ważną prośbą. Otóż towarzyszący mnichowi w podróży Arseniusz zasłabł z powodu braku wody. Julian przyjmując pozycję klęczącą wyprosił u Boga wytryśnięcie źródła, dzięki któremu młody człowiek ugasił pragnienie. Ostatnia wzmianka o klęczącym mnichu dotyczy Symeona Starszego. Jest ona o tyle ciekawa, że asceta ten miał trwać w tej postawie przez cały tydzień ${ }^{119}$. Musiało to być bardzo uciążliwe, oczywiście o ile relacja Teodoreta jest w tym wypadku prawdziwa. Sam autor, opisując to zdarzenie, powołuje się jedynie na pogłoski. Postawę klęczącą stosowano także w trakcie pokuty ${ }^{120}$, choć Teodoret nie podaje takiego przykładu. Nawyk modlenia się prawie wyłącznie na kolanach stał się bardzo popularny od średniowiecza pod wpływem zwyczajów germańskich ${ }^{121}$.

Postawa klęcząca budziła pewne kontrowersje w Kościele. Chodziło nie o to, czy powinno się ją stosować, ale kiedy należy z klękania zrezygnować. O sporze tym wspominał Tertulian: ,również co do klęczenia w czasie modlitwy różnie się zapatrują ci, którzy uchylają się od tego w sobotę. W sprawie tej powstał wielki spór między różnymi Kościołami" 122 . Powstrzymywanie się od przyjmowania tej postawy w sobotę było konsekwencją przejmowania przez część chrześcijan tradycji żydowskiego szabatu. Tertulian zalecał, aby unikać klękania $\mathrm{w}$ niedziele ${ }^{123}$. Teodoret nie informował czy syryjscy mnisi stosowali jakieś ograniczenia $w$ tej kwestii.

W trakcie modlitwy przyjmowano także postawę leżącą. Wspominał o niej Teodoret w odniesieniu do Jakuba:

\footnotetext{
115 Tamże IV 12, PG 82, 1349D, ŹM 7, 128.

${ }^{116}$ Por. Szpyrka, Gest w modlitwie (II), s. 59.

117 Theodoretus, Historia religiosa II 18, PG 82, 1321B, ŹM 7, 97.

${ }^{118}$ Tamże II 7, PG 82, 1313A, ŹM 7, 88.

${ }^{119}$ Por. tamże VI 12, PG 82, 1364B, ŹM 7, 143.

${ }^{120}$ Por. Szpyrka, Gest w modlitwie (II), s. 61.

${ }^{121}$ Por. H. Wójtowicz - J. Szymusiak, Antologia modlitwy patrystycznej, Sandomierz 1971, 16.

${ }^{122}$ Tertullianus, De oratione 23, PL 1, 1191A, thum. Kania, s. 55.

${ }^{123}$ Por. tamże, tłum. Kania, s. 56.
} 
„często gdy padał śnieg przez trzy dni i tyleż nocy, znajdowano go leżącego twarzą ku ziemi i modlącego się pod taką ilością śniegu, że nie było widać nawet kawałka szmat, w które był odziany"124.

Również w tym wypadku byłby to dość ekstremalny sposób modlenia się, zagrażający zdrowiu, a nawet życiu tego ascety. Należy tu wspomnieć, że chorobom Jakuba Teodoret poświęcał wiele miejsca w swym opisie ${ }^{125}$. Wydaje się, że w kwestii modlitw Jakuba można zaufać relacji biskupa Cyru, który nie tylko dobrze znał tego ascetę, ale także spędzał w jego towarzystwie wiele czasu. W czasie choroby chrześcijanie mogli się modlić w pozycji leżącej lub przyjmować postawę siedzącą ${ }^{126}$. Niektórzy mieli co do tej ostatniej pewne wątpliwości. Tertulian bardzo stanowczo zwalczał siadanie w trakcie modlitwy i po jej zakończeniu, ponieważ uznawał to za obyczaj pogański ${ }^{127}$. Teodoret nie podał przykładów ascetów modlących się na siedząco.

Elementem modlitwy był także znak krzyża. Był to symbol uświęcenia i błogosławieństwa, który stosowano zarówno w odniesieniu do własnej osoby, jak i do innych ludzi, czy nawet przedmiotów ${ }^{128}$. Teodoret wspominał o nim trzykrotnie, ale nie przy okazji opisu modlitw, tylko błogosławieństw. Skoro jednak syryjscy mnisi używali tego gestu do poświęcania wody, to mogli go także stosować w trakcie swoich modlitw. Prawie zawsze, wspominając o tym geście, nazywał go zbawczym lub zbawiennym. Przykładowo Afraates, błogosławiąc wodę, ,uczynił nad nią znak zbawiennego krzyża"129. Wodę błogosławił także Macedoniusz ${ }^{130}$. W obydwu tych przypadkach wypicie takiej wody miało przywracać zdrowie. O zbawczym znaku krzyża mowa jest po raz trzeci w przypadku uzdrowienia matki Teodoreta przez pustelnika Piotra Galatę, który ,,położył rękę na jej oku, uczynił znak zbawiennego krzyża i tak odpędził chorobę"131. W Piśmie Świętym nie ma o nim wyraźnie mowy, a pierwsze wzmianki o stosowaniu tego symbolu pochodzą z lat 150$200^{132}$. Początkowo znak krzyża czyniono zasadniczo na czole, potem także na oczach, uszach, a nawet nosie. Od IV w. krzyżem znaczono także piersi ${ }^{133}$.

${ }^{124}$ Por. Theodoretus, Historia religiosa XXI 13, PG 82, 1440A, ŹM 7, 231.

${ }^{125}$ Teodoret nie wyjaśnia jednak, co było powodem tych chorób. Jest bardzo prawdopodobne, że główną ich przyczyną była dieta tego ascety. Jego choroby miały bowiem związek z układem pokarmowym. Nie można jednak wykluczyć, że kilkudniowe leżenie na śniegu pogarszało stan jego zdrowia.

${ }^{126}$ Por. Małunowiczówna, Modlitwa prywatna, s. 214.

${ }^{127}$ Por. Tertullianus, De oratione 16-17, PL 1, 1171A - 1176A, thum. Kania, s. 55.

${ }^{128}$ Por. S. Longosz, Znak krzyża świętego w życiu starożytnych chrześcijan, TST 8 (1981) 221.

${ }^{129}$ Theodoretus, Historia religiosa VIII 11, PG 82, 1376B, ŹM 7, 156.

${ }^{130}$ Por. tamże XIII 9, PG 82, 1405A, ŹM 7, 190.

${ }^{131}$ Tamże IX 7, PG 82, 1384B, ŹM 7, 164.

${ }^{132}$ Por. Longosz, Znak krzyża świętego, s. 221.

${ }^{133}$ Por. tamże, s. 230. Na temat kultu krzyża por. też S. Bralewski, Życie religijne mieszkańców Konstantynopola, w: Konstantynopol Nowy Rzym. Miasto i ludzie w okresie wczesnobizantyńskim, red. M.J. Leszka - T. Wolińska, Warszawa 2011, 409-418. 
6. Rodzaje i kolejność modlitw. Duża dowolność istniała w kwestii rodzajów modlitw i ich kolejności. W Historia religiosa jest sporo informacji na ten temat. W sprawie porządku, jaki pustelnicy syryjscy przyjmowali w swoich modlitwach, Teodoret wypowiadał się trzykrotnie. W przypadku Marcjana porządek był następujący:

„po modlitwie następowała psalmodia, po psalmodii modlitwa, po jednym i drugim czytanie słowa Bożego""134.

Dokładnie taką samą kolejność zachowywał Publiusz. Zgodnie ze słowami Teodoreta

„nikt nigdy nie widział, aby choć przez małą chwilę w ciągu dnia zażywał wytchnienia, lecz modlitwa następowała po śpiewaniu psalmów, po modlitwie śpiewanie psalmów, a po jednym i drugim czytanie Boskich słów"135.

Uczniowie Juliana natomiast modlili się parami, na zmianę śpiewając psalmy i oddając cześć Bogu ${ }^{136}$.

Teodoret z Cyru wyraźnie odróżniał modlitwę od śpiewania psalmu ${ }^{137}$. Współcześnie takie rozróżnienie nie jest już dokonywane, ale dla pierwszych mnichów musiało ono być czymś oczywistym, skoro w swoim dziele Teodoret je eksponuje. Psalmodia w ówczesnych czasach uznawana była za lekturę Pisma Świętego, natomiast w modlitwie widziano rozmowę czy obcowanie z Bogiem. Starożytni mnisi nie uważali więc czytania Pisma (a więc także psalmów) za modlitwę, ponieważ nie zwracali się w ten sposób bezpośrednio do Boga, a jedynie zapoznawali z Jego słowami. U Ewagriusza modlitwa następowała zawsze po psalmodii jako wyraz odpowiedzi człowieka na fragment tekstu Pisma Świętego ${ }^{138}$. Z przytoczonych fragmentów Historia religio$s a$ wynika, że mnisi w Syrii nie stosowali się do tego zalecenia, ale modlili się i śpiewali psalmy wymiennie.

Nawet jeśli syryjscy anachoreci nie uważali psalmów za dosłownie rozumianą modlitwę, to ich recytowanie (czytanie lub śpiewanie) było niezwykle popularne zarówno wśród mnichów, jak i innych wyznawców Chrystusa. Tradycję odmawiania psalmów chrześcijaństwo przejęło z żydowskiej prak-

${ }^{134}$ Theodoretus, Historia religiosa III 2, PG 82, 1325B, ŹM 7, 101.

${ }^{135}$ Tamże V 2, PG 82, 1352D, ŹM 7, 131.

${ }^{136}$ Por. tamże II 5, PG 82, 1309B-C, ŹM 7, 85.

${ }^{137}$ Słowo „psalm”, wywodzące się z języka greckiego ( $\psi \alpha \lambda \mu$ ó $)$ jest tłumaczeniem odpowiedniego terminu hebrajskiego i oznacza śpiew z instrumentem strunowym. Etymologia tego słowa nawiązuje do trącania cięciwy łuku lub napiętej struny. Pierwotny termin hebrajski natomiast oznacza pochwałę. Tłumaczenie greckie akcentuje sposób wykonania utworu, podczas gdy termin hebrajski kładzie nacisk na treść psalmu. Najogólniej psalm zdefiniować można jako hebrajską pieśń religijną. Zbiór 150 tych utworów wchodzi w skład Starego Testamentu i jest kanonem liturgii żydowskiej i chrześcijańskiej. Tradycyjnie ich autorstwo przypisywano królowi Dawidowi.

${ }^{138}$ Por. Bunge, Ewagriusz z Pontu, s. 26. 
tyki synagogalnej, wzbogacając je o elementy greckie ${ }^{139}$. Połączenie tekstu z melodią ułatwiało zapamiętywanie, co mogło być jedną z przyczyn popularności tego rodzaju modlitwy. Znane są przypadki pamięciowego opanowania przez mnicha całego Psałterza ${ }^{140}$. Recytowanie psalmów uważano za najlepszą ochronę przed atakami demonów ${ }^{141}$. Mnisi syryjscy, podobnie jak ci pochodzący z innych części chrześcijańskiego świata, włączyli Psałterz do swoich modlitw codziennych. Historia religiosa daje na to wiele dowodów. Teodoret mówi o recytacji, śpiewaniu lub czytaniu psalmów aż dwanaście razy, co wskazuje na częste wykonywanie psalmów przez mnichów. Przykładowo o Julianie wiemy, że:

„rozkoszą zaś i upojeniem, i ucztą wyśmienitą był dla niego śpiew psalmów

Dawida i stałe obcowanie z Bogiem. W tym był nienasycony"142.

Swój sposób modlitwy przekazał on swoim uczniom. Wychodzili oni na pustynię w parach. Jeden z nich modlił się na kolanach, „drugi zaś, stojąc, miał śpiewać piętnaście Dawidowych psalmów"143, po czym zamieniali się rolami. Po raz kolejny widać tu rozróżnienie na modlitwę i towarzyszącą jej psalmodię. Wyznawcy judaizmu $\mathrm{w}$ okresie świątyni ${ }^{144}$ wykonywali psalmy przy akompaniamencie instrumentów strunowych lub fletów ${ }^{145}$. Psalmodia, którą przejęli chrześcijanie, wykształciła się jednak później, w okresie synagogalnym. Polegała ona bardziej na recytowaniu niż śpiewaniu. Utwór wykonywano jednym tonem z przedłużeniem słów stojących przy cezurze $^{146}$ i na końcu tekstu ${ }^{147}$. W Historia religiosa nie ma żadnych informacji na temat sposobu, w jaki wykonywano psalmy. Inni asceci, którzy modlili się w ten sposób to Marcjan ${ }^{148}$, Publiusz ${ }^{149}$, Symeon Starszy ${ }^{150}$, Teodozjusz ${ }^{151}$,

${ }^{139}$ Por. K. Wojciechowska, Hymn, psalm, chorat - próba uściśleń genealogii, „Liturgia Sacra” 8 (2002) 299.

${ }^{140}$ Por. Małunowiczówna, Modlitwa prywatna, s. 207.

${ }^{141}$ Por. Vööbus, History of ascetism, s. 289.

${ }^{142}$ Theodoretus, Historia religiosa II 2, PG 82, 1308A, ŹM 7, 82.

${ }^{143}$ Tamże II 5, PG 82, 1309C, ŹM 7, 85.

${ }^{144} \mathrm{~W}$ latach 970-586 prz. Chr.

${ }^{145}$ Por. E. Ostaszewska, Psalm, w: Od psalmu i hymnu do songu i liedu. Zagadnienia genologiczne: rodzaj-gatunek-utwór, red. M. Tomaszewski, Muzyka i liryka 7, Kraków 1998, 11.

${ }^{146} \mathrm{~W}$ muzyce termin ten oznacza przerwę, dzielącą utwór na frazy, motywy, okresy. Czasami wskazuje na konieczność wzięcia oddechu.

${ }^{147}$ Por. Ostaszewska, Psalm, s. 11.

${ }^{148}$ Por. Theodoretus, Historia religiosa III 2, PG 82, 1325A, ŹM 7, 101.

${ }^{149}$ Por. tamże V 2, PG 82, 1352D, ŹM 7, 131.

${ }^{150}$ Por. tamże VI 10, PG 82, 1364A, ŹM 7, 142 - 143.

${ }^{151}$ Por. tamże X 2, PG 82, 1389A, ŹM 7, 171. 
Jakub $^{152}$, Limnajusz ${ }^{153}$, Symeon Słupnik ${ }^{154}$, Domnina ${ }^{155}$. Do popularności psalmów w dużej mierze przyczyniać się mogło powszechne ich wykorzystywanie $\mathrm{w}$ czasie oficjalnych nabożeństw ${ }^{156}$. Niektóre $\mathrm{z}$ psalmów weszły na stałe do modlitw porannych (Psalmy: 4, 5 i 62) oraz wieczornych (Psalm 140) ${ }^{157}$. Teodoret wymieniał w Historia religiosa przykłady wielu psalmów, które odmawiali mnisi ${ }^{158}$. W przypadku Marcjana autor podaje fragment psalmu pierwszego ${ }^{159}$. Najwięcej miejsca tego rodzaju modlitwie poświęcał opisując Juliana. Teodoret wymieniał nawet pojedyncze zdania z psalmów, które wykorzystywał ten asceta. Zgodnie ze słowami biskupa Cyru Julian:

„stale wołał: «Jak słodkie są podniebieniu memu słowa Twoje, ponad miód ustom moim» (Ps 118, 103). Usłyszał też, jak błogosławiony Dawid mówi: «Sądy Pańskie prawdziwe, wszystkie razem sprawiedliwe. Bardziej pożądane nad złoto i mnogie kamienie drogie, a słodsze niż miód i plastr miodowy» (Ps 18, 10-11). I znów usłyszał jak mówi: «Rozkoszuj się w Panu, a da ci, czego pożąda twe serce» (Ps 36, 4). I znowu: «Niech się weseli serce szukających Pana» (Ps 104, 3), i: «Skosztujcie, a obaczcie, iż Pan jest dobry» (Ps 33, 9). A także: «Pragnęła dusza moja Boga mocnego, żywego» (Ps 41, 3) oraz: «Przylgnęła moja dusza do Ciebie» (Ps 62, 9)" ${ }^{\prime 160}$.

Kolejny rodzaj modlitwy - hymny, były w swojej formie bardzo zbliżone do psalmów. Bardzo często mówi się o psalmach jako pieśniach o charakterze hymnicznym ${ }^{161}$. Oba pojęcia nie są jednak ze sobą tożsame. Główną różnicą była kwestia ich pochodzenia - część hymnów miała korzenie pozabiblijne ${ }^{162}$. Geneza tego rodzaju modlitwy sięga czasów antycznych. Najstarsze znane utwory tego gatunku to staroegipskie hymny z III tysiąclecia prz. Chr. czy sumeryjskie z II tysiąclecia przed Chrystusem ${ }^{163}$. Swoje hymny chrześcijanie przejęli z tradycji żydowskiej ${ }^{164}$. $Z$ czasem jednak duży wpływ na ten rodzaj modlitwy wywarła tradycja pogańska ${ }^{165}$. W Historia religiosa słowo hymn

\footnotetext{
${ }^{152}$ Por. tamże XXI 17, PG 82, 1441C, ŹM 7, 234.

${ }^{153}$ Por. tamże XXII 7, PG 82, 1456C, ŹM 7, 249.

${ }^{154}$ Por. tamże XXVI 6, PG 82, 1469A, ŹM 7, 266.

${ }^{155}$ Por. tamże XXX 1, PG 82, 1492D, ŹM 7, 295.

${ }^{156}$ Por. Małunowiczówna, Antologia modlitwy wczesnochrześcijańskiej, s. 28.

${ }^{157}$ Por. taż, Modlitwa prywatna, s. 207.

${ }^{158}$ Por. Theodoretus, Historia religiosa I 10, PG 82, 1300D - 1301A, ŹM 7, 75 (Ps 61, 5; 54, 22; 105, 30-31); III 2, PG 82, 1325A, ŹM 7, 101 (Ps 1, 2-3); XII 2, PG 82, 1396C, ŹM 7, 179-180 (Ps 54, 7); XV 1, PG 82, 1413D, ŹM 7, 201 (Ps 36, 4).

${ }^{159}$ Por. tamże III 2, PG 82, 1325A, ŹM 7, 101.

${ }^{160}$ Tamże II 2, PG 82, 1308A-B, ŹM 7, 82.

${ }^{161}$ Por. Wojciechowska, Hymn, psalm, chorat, s. 291-292.

${ }^{162}$ Por. tamże, s. 292.

${ }^{163}$ Por. S. Czajkowski, Hymn, w: Od psalmu i hymnu do songu i liedu, s. 25.

${ }^{164}$ Por. tamże, s. 26.

${ }^{165}$ Por. E. Wellesz, History of Byzantine music and hymnography, Oxford 1961, 146.
} 


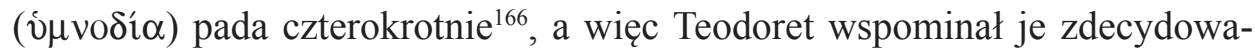
nie rzadziej niż psalmy. To, że Teodoret przekazywał tak skąpe informacje na temat hymnów śpiewanych przez syryjskich pustelników, wcale nie oznacza, że niewielu z nich stosowało ten rodzaj modlitwy. Przeciwnie, należy tu wziąć pod uwagę fakt, że to właśnie kościół syryjski był jednym z pierwszych miejsc ${ }^{167}$, gdzie powstały hymny. W IV w. w Syrii wykształciła się hymnodia stroficzna, opierająca się na zasadzie akcentowo-stroficznej ${ }^{168}$.

Wiemy więc, że ten rodzaj modlitwy zalecali swoim uczniom asceci Julian $^{169}$ i Publiusz ${ }^{170}$, również Symeon Słupnik ,śpiewał Bogu hymny"171. W przypadku Domniny natomiast pada określenie ,"pochwalne hymny” ${ }^{172}$, co bardzo dobrze oddaje charakter tego rodzaju modlitwy. Bardzo często były to bowiem modlitwy laudacyjne ${ }^{173}$. Adresatem hymnu, także pogańskiego, było bóstwo. W przypadku modlitw chrześcijańskich najczęściej zwracano się do Jezusa. Układano także hymny skierowane do Boga Ojca, ale robiono to rzadziej (częściej oddawano mu cześć przy pomocy psalmów). Hymny służyły przede wszystkim uhonorowaniu Syna ${ }^{174}$.

Z kwestią modlitwy łączyło się także czytanie Pisma Świętego ${ }^{175}$. Teodoret informował o tym pięć razy ${ }^{176}$. Dwukrotnie informacja ta dotyczy Marcjana. Wiemy dzięki temu, że mnisi czytali Biblię nie tylko w dzień, ale także w nocy. Biskup Cyru wspominał, że uczeń Marcjana, Euzebiusz „,pewnej nocy chciał zobaczyć, co czyni Marcjan"177. Obserwował swojego mistrza, gdy ten „trzymał w ręku księgę i szukał w niej niezniszczonego skarbu woli Bożej”"178.

${ }^{166}$ Theodoretus, Historia religiosa II 5, PG 82, 1309C, ŹM 7, 85; V5, PG 82, 1353D, ŹM 7, 133; XXVI 6, PG 82, 1469A, ŹM 7, 266; XXX 1, PG 82, 1492D, ŹM 7, 295.

167 Hymnodia chrześcijańska rozwijała się początkowo głownie w Kościele Wschodnim. Oprócz Kościoła syryjskiego hymny powstawały także w Konstantynopolu.

${ }^{168}$ Por. Czajkowski, Hymn, s. 27.

${ }^{169}$ Por. Theodoretus, Historia religiosa II 5, PG 82, 1309C, ŹM 7, 85.

${ }^{170}$ Por. tamże V 5, PG 82, 1353D, ŹM 7, 133.

${ }^{171}$ Tamże XXVI 6, PG 82, 1469A, ŹM 7, 266.

172 Tamże XXX 1, PG 82, 1492D, ŹM 7, 295.

${ }^{173}$ Por. Wojciechowska, Hymn, psalm, chorat, s. 291.

${ }^{174}$ Por. tamże, s. 292.

${ }^{175}$ Por. Canivet, Le monachisme syrien, s. 279-281.

176 Theodoretus, Historia religiosa III 2, PG 82 1325A, ŹM 7, 101; III 6, PG 82, 1328B, ŹM 7, 104; IV 6, PG 82, 1344C, ŹM 7, 122; V 2, PG 82, 1352D, ŹM 7, 131; XXVIII 4, PG 82, 1488D, ŹM 7, 289. Wszystkie wymienione przykłady dotyczą właśnie ascetów żyjących we wspólnotach. Nie oznacza to oczywiście, że anachoreci nie czytali Biblii. Brak wzmianek na ten temat niczego nie przesądza. Dla porównania wskazać można, że Teodoret ani razu nie wspomina, aby syryjscy mnisi modlili się słowami modlitwy „Ojcze nasz”, a przecież według Ojców Kościoła stanowi ona wzór modlitwy chrześcijańskiej. Modlitwa ta była wielokrotnie komentowana (np. przez Jana Kasjana, Tertuliana, Cypriana, czy Orygenesa).

${ }_{177}$ Tamże III 6, PG 82, 1328B, ŹM 7, 104.

${ }^{178}$ Tamże, PG 82, 1328C, ŹM 7, 104. 
Kolejnym ascetą czytającym Biblię był Publiusz ${ }^{179}$, również w przypadku Talelajosa dowiadujemy się, że „czytał święte Ewangelie i bardzo starannie zbierał owoce swej lektury"180. Wiarygodność tej informacji jest tym większa, że Teodoret podkreślał, iż sam był tego świadkiem. W przypadku Euzebiusza i Ammiana, biskup opisywał sposób, w jaki ci asceci komentowali Pismo. Zgodnie ze słowami biskupa Cyru ,jeden czytał tekst świętych Ewangelii, drugi odsłaniał sens niejasnych miejsc" ${ }^{181}$. Lektura Pisma połączona z jego komentowaniem była powszechną praktyką w klasztorach syryjskich. Posiadały one biblioteki i skryptoria ${ }^{182}$.

Specyficznym rodzajem modlitwy syryjskich ascetów była także kontemplacja $^{183}$. W pewnym sensie traktować ją można jako kulminację modlitwy ${ }^{184}$. Miała ona dawać ludziom możliwość wpatrywania się w Boga ${ }^{185}$. W Historia religiosa informacje o mnichach modlących się w ten sposób pojawiają się trzykrotnie. Pierwsza informacja dotyczy Acepsymasa, który „kontemplował Boga" ${ }^{186}$. Dla Euzebiusza natomiast bardzo uciążliwe było „obcowanie z tłumem, gdyż stale zatopiony w kontemplacji Boga, nie chciał od niego odrywać myśli" ${ }^{187}$. Trzecim przykładem opisanym w Historia religiosa są ascetki Marana i Cyra, które „kontemplując piękno Oblubieńca, znoszą chętnie i łatwo wysiłek swego biegu"188. Ściśle rzecz biorąc, praktyka ta nie ma pochodzenia biblijnego. Była jednak bardzo ważnym elementem życia religijnego chrześcijan - pojęcie to Ojcowie Kościoła przejęli z filozofii neoplatońskiej ${ }^{189}$. Już od pierwszych wieków istnienia chrześcijaństwa oznaczała ona modlitwę pogłębioną, bardziej zaawansowaną ${ }^{190}$.

Dla syryjskich mnichów, podobnie jak dla tych pochodzących z innych części chrześcijańskiego świata, modlitwa miała znaczenie kluczowe - w końcu całe swoje życie poświęcali oni, aby zbliżyć się do Boga, a modlitwa, jak to starano się wykazać na początku artykułu, była rozumiana jako rozmowa z Bogiem, czyli bezpośredni kontakt z Nim. Wszystkie ascetyczne wyrzecze-

\footnotetext{
${ }^{179}$ Por. tamże V 2, PG 82, 1352D, ŹM 7, 131.

${ }^{180}$ Tamże XXVIII 4, PG 82, 1488D, ŹM 7, 289.

${ }^{181}$ Tamże IV 6, PG 82, 1344C, ŹM 7, 122.

${ }^{182}$ Por. E. Wipszycka, Charakter i formy ascetyzmu syryjskiego, w: ŹM 7, 22.

${ }^{183}$ Por. Canivet, Le monachisme syrien, s. 278-279.

${ }^{184}$ Por. Maciuszko, Modlitwa, s. 110.

${ }^{185}$ Por. H. Dybski, Modlitwa w ujęciu Jana Kasjana, VoxP 19 (1999) t. 36-37, 342.

186 Theodoretus, Historia religiosa XV 1, PG 82, 1413D, ŹM 7, 201. W oryginalnym tekście

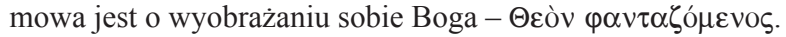

${ }^{187}$ Tamże XVIII 2, PG 82, 1425D, ŹM 7, 217.

${ }^{188}$ Tamże XXIX 6, PG 82, 1492B, ŹM 7, 293.

${ }^{189}$ Por. M. Chodyko, Co Biblia mówi na temat kontemplacji, PP 124 (2007) nr 1, 87-99.

${ }^{190}$ Por. tamże, s. 87-99.
} 


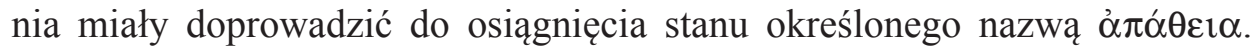
Człowiek, który osiągnął taki stan mógł - zgodnie z przekonaniem ascetów - oddać się nieprzerwanej kontemplacji niebiańskiej rzeczywistości. Rolą modlitwy była pomoc w uzyskaniu tego stanu, a oznaką beznamiętności była m.in. umiejętność modlenia się bez wyobrażania sobie w tym czasie innych rzeczy. Modlitwa miała za zadanie pomóc ascecie w opanowaniu jego potrzeb cielesnych, zwracała umysł mnicha ku Bogu, odrywając go jednocześnie od spraw świata doczesnego. Jednocześnie modlitwa była wyrazem wiary mnicha, gdyż za jej pośrednictwem oddawał on cześć Bogu, zwracał się do Niego z prośbami czy dziękczynieniami. Bogactwo informacji zawartych przez biskupa Cyru w Historia religiosa składa się na interesujący obraz modlitwy syryjskich ascetów. Bardzo ważną rolę pełniły w niej wielokrotnie wzmiankowane psalmy. W trakcie swojej modlitwy asceci przyjmowali różne postawy i wykonywali konkretne gesty, z których każdy miał swoją symbolikę. Osiągnięcie doskonałości w modlitwie było celem, dla którego osiągnięcia mnisi podejmowali wiele umartwień. Przykładowo, dzięki ograniczaniu snu mieli oni nadzieję zyskać jak najwięcej czasu na rozmowę z Bogiem. Natomiast rezygnacja z kontaktów z ludźmi ułatwić miała skupienie. Teodoret wielokrotnie podkreśla, jak wielką moc miała modlitwa opisywanych przez niego mnichów. Każdy asceta, który w swojej modlitwie zwracał się do Boga z jakąś prośbą, natychmiast otrzymywał to, czego potrzebował. Historia religiosa pełna jest więc opisów niezwykłych dokonań syryjskich ascetów, którzy siłą swojej modlitwy mieli uzdrawiać czy nawet przywracać życie.

\section{THE ROLE OF PRAYER IN THE LIFE OF SYRIAN MONKS ACCORDING TO THEODORETUS OF CYRUS}

\section{(Summary)}

Prayer was a basic goal of the lives of Christian monks. Historia religiosa by Theodoretus of Cyrus conveys a lot of valuable information on the subject of prayer of Syrian ascetics. The bishop of Cyrus used the notion of prayed to refer to any kind of requests and begging or thanksgiving and admiration. Theodoretus recorded particularly numerous examples of recoveries, which occurred by dint of intercessive prayer of ascetics. Monks prayed at different times of a day and in various postures (standing, lying or kneeling), they were also familiar with many kinds of prayer and addressed God with varied intentions. Historia religiosa informs us as well about gestures that accompanied prayers, such as bows, raising arms and eyes to the sky and places where it could be said. An important issue discussed by Theodoretus was the time of praying. In Historia religiosa we can find references to the ideal of incessant prayer and to morning and evening prayers typical for Christians. The aim of prayer was to help ascetics control their bodily needs, it drew the mind of an ascetic towards God, tearing them, at the same time, 
from worldly issues. Prayer was also a reflection of monk's faith, since through it, they worshipped God, referred to him their requests and thanksgiving.

Key words: Ascetism, hymns, monasticism, prayer, contemplation, psalms, Syria, Theodoret of Cyrus.

Słowa kluczowe: Asceza, hymny, monastycyzm, modlitwa, kontemplacja, psalmy, Syria, Teodoret z Cyru. 